\title{
The Evolution of Population Distribution on the Iberian Peninsula: A Transnational Approach (1877-2001)
}

LUÍS ESPINHA DA SILVEIRA, DANIEL ALVES, MARCO PAINHO, ANA CRISTINA COSTA AND ANA ALCÂNTARA

\section{QUERY SHEET}

This page lists questions we have about your paper. The numbers displayed at left can be found in the text of the paper for reference. In addition, please review your paper as a whole for correctness.

Q1. Au: Please spell out EEC.

Q2. Au: Ok to add "(c)" before the last part of this sentence?

Q3. Au: Please spell out DTM.

Q4. Au: Ok to add "See Figure 1" here?

Q5. Au: In Pérez Moreda 2004 reference, please provide editor(s).

\section{TABLE OF CONTENTS LISTING}

The table of contents for the journal will list your paper exactly as it appears below: 


\title{
The Evolution of Population Distribution on the Iberian Peninsula: A Transnational Approach (1877-2001)
}

\author{
LUÍS ESPINHA DA SILVEIRA \\ DANIEL ALVES \\ Instituto de História Contemporânea, Universidade Nova de Lisboa \\ MARCO PAINHO \\ ANA CRISTINA COSTA \\ Instituto Superior de Estatística e Gestão da Informação, Universidade Nova de Lisboa \\ ANA ALCÂNTARA \\ Instituto de História Contemporânea, Universidade Nova de Lisboa
}

\begin{abstract}
Surpassing the national perspective usually adopted, the authors confirmed the existence of a pattern of population distribution common to the whole Iberian Peninsula in the long run. This pattern is clearly associated with geographical factors. These 5 variables seem to have more weight in explaining changes between $1877 / 78$ and 1940 than in the period from 1940 to 2001 . The observation of the cross-border region has shown that proximity to the frontier has not generated any distinct pattern of population density on either side of the boundary line. The spatial coherence of the observed phenomena throughout the Peninsula and of its evolution, independent of the border between states, reinforces the importance
\end{abstract}

This work begun within the research project, "The Development of European Waterways, Road and Rail Infrastructures: A Geographical Information System for the History of European Integration (1825-2005)," developed under European Science Foundation EUROCORES programme. In Portugal, it was funded by Fundação para a Ciência e a Tecnologia. The good relationships established with the Spanish team allowed the integration of Josep Puig-Farré in our group from 2009 to 2011, a period in which we began developing the historical geographical information system on the Iberian Peninsula. The problems that we faced and the methodology to solve them were presented in several conferences in 2010, and the Iberian Peninsula was then integrated in our geographical information system website (http://atlas.fcsh.unl.pt/). We benefited from the discussions with Jordi Marti-Henneberg and Xavier Franch in July 2011 and with the colleagues attending the workshop " $L$ ' Ús dels SIG en l' Estudi de la Integració Europea (1870-2010)" held in Barcelona in March 2012, also organized by Jordi Marti-Henneberg, and funded by European Union (Jean Monnet 200215_LLP-1-ESAJMIC).

Address correspondence to Luís Espinha da Silveira, Instituto de História Contemporânea, Faculdade de Ciências Sociais e Humanas, Universidade Nova de Lisboa, Av. de Berna 26-C, 1069-061 Lisboa, Portugal.E-mail: In.silveira@sapo.pt of geographic factors in their explanation. At the same time, this verification opens up new issues related to the effect of national political and economic policies.

Keywords: border studies, geographic information systems, Iberian Peninsula, spatial population distribution, transnational history

$\mathrm{P}$ opulation distribution patterns in Portugal and in Spain have always been an important research topic. Additionally, given the current dramatic imbalance between a small group of densely populated and wealthy regions and the rest of the territories in both countries, this subject has also become a matter of concern for society as a whole. In fact, the differences in wealth, economic, and demographic dynamism and the regional disparities in access to education, health, and other public services seriously endanger territorial cohesion and the principle of equal opportunities among citizens. Therefore, revisiting the issue of population distribution from a transnational perspective and in the long run is not only to address an important subject for research in humanities and social sciences, but to contribute to the understanding of the roots of a current social problem of great relevance.

In this article, surpassing the national perspective usually adopted, we tried to verify the existence of a spatial pattern of population distribution on the Peninsula as a whole and study its evolution. We also sought to evaluate the relevance of geographical factors to explain this pattern, and we wanted to 
40 analyze the importance of the Spanish-Portuguese border in spatial population distribution. In the conclusion, we call the attention to some of the implications of our findings concerning the effect of political and economic policies on patterns of concentration/dispersion of population. The transnational

45 approach and the in-depth spatial analysis supported by the geographical information system (GIS) are the main contributions of this article to the research on this subject.

The literature published in Spain about territorial population distribution and its evolution over the nineteenth

50 and twentieth centuries is abundant. A list of the works produced up until a few years ago can be found in Olga Cos Guerra and Pedro Reques Velasco (2005). Since then, research has continued, presenting remarkable results. We will focus our attention on these more recent articles. It

55 has been recently argued that Europe's regional inequalities worsened between 1870 and 2000. Patterns of population distribution over the same period show "stability in both underpopulated and very densely populated areas," and this happened "despite enormous changes in the factors that

60 have determined the location of population and economic activities since 1870" (Martí-Henneberg 2005, 277, 279). Analyzing population densities within a group of European countries of different sizes and geographical positions from 1850 to 2000, Maria Isabel Ayuda, Fernando Collantes, and

65 Vicente Pinilla (2010a) came to similar conclusions. The explanation put forth by these authors lay in the regional differences in the spread of industrialization and modern economic growth, which increased population disparities thereafter (although without profoundly affecting the spatial

70 pattern existing in the pre-industrial era). In 2000, Portugal and Spain would be amongst the countries where such disparities were most pronounced (Dobado González 2006; Ayuda et al. 2010a).

Concerning Spain, regardless of the time period or the

75 scale of the geographical framework, researchers agree upon the existence of a considerably stable territorial pattern of population distribution. The latter is characterized by the contrast between the coastal lowlands, where population is concentrated, and the depopulated higher territories of the

80 interior. Madrid, located at the center of the Peninsula, is the most important exception to this general pattern. Vicente Pérez Moreda (2004), although working at the large regional area level, found evidence of such distribution as early as 1787. Rafael Dobado González (2006) and Ayuda et al.

85 (2010b) confirmed the same pattern at the provincial level for the period 1787 to 2000. Finally, Cos Guerra and Reques Velasco (2005) and Franciso Goerlich Gisbert and Matilde Mas Ivars $(2006,2008)$ came to the same conclusion on the municipal scale for the twentieth century. In addition, Goer-

90 lich Gisbert and Mas Ivars (2008) and Ayuda et al. (2010a) statistically confirmed the trend for population to concentrate in the areas that already had a higher population density at the beginning of the various periods under analysis by the two groups of researchers.
Accordingly, with the exception of Pérez Moreda (who did not express his view on this issue), these authors underlined the importance of geographical factors (altitude, distance to coast, and rainfall) to explain the location of population.

The influence of geographical factors on economic development and the distribution of the world population, two distinct but inter-related phenomena, has been advocated by historians such as Paul Bairoch (1971, 118-20) and economists such as Andrew Mellinger, Jeffrey Sachs, and John Gallup (2000). The former drew attention to the effects of climate on agricultural productivity and human health. He also pointed out that climatic differences hampered the spread of agricultural innovations developed in temperate regions, which were decisive in triggering the industrialization process. To these aspects Mellinger and colleagues (2000) added the importance of access to navigable rivers and the sea, by the effect that this access has on transport.

However, if the geographical determinism of the past has been abandoned, it has not been possible to achieve a consensual view on the importance of the natural conditions in the spatial distribution of wealth and population. The Economic Geography, in general, has not given great emphasis to this issue (Wood and Roberts 2011). The New Economic Geography itself, initiated by Paul Krugman (1998), although it has reintroduced space in economic analysis does not grant importance to physical geography as well. For instance, Pierre-Philippe Combes, Thierry Mayer, and JacquesFrançois Thisse (2006) argued that physical factors should be taken into account in explaining geographic distribution of development on a global scale, but not in the analysis of regional inequalities in developed countries. In this case, the relevant factors to understand the concentration of economic activity and population are the combined effects of market size, economies of scale, and transport costs (Krugman 1993).

The perspectives of New Economic Geography and those of Mellinger and colleagues can however be complementary, as the latter authors suggested: "It could be, for example, that physical geography helps to explain initial differences in outcomes across regions, and that new economic geography helps to account for ways in which those initial differences are magnified" $(2000,172)$. Ayuda and colleagues' work on Spain explores this path (2010b). In fact, these authors suggested that geographical factors, namely altitude, distance to coast, and rainfall, which have a great influence on agricultural productivity and transportation, were decisive in explaining the concentration of economic activity and population prior to industrialization. When this process began, industries, in a search for market access, tended to localize themselves in these most populated areas. Thereafter the interaction between economy and population turned out to be a mutually reinforcing process, whereby the richer regions tended to attract a migrant population from poorer areas, which in turn helped to develop the territories where the modern economic sectors were concentrating (Paluzie et al. 
150 2009; Collantes and Pinilla 2011). The latter also profited from scale economies and decreases in transportation costs. For this reason, at a later stage, geographical factors, though still important to explain population location, began to share this role with other factors related to this cumulative effect

155 (Ayuda et al. 2010b).

Historians have long affirmed that the Portuguese population historically presented a denser concentration on the coastal strip to the North of the Tagus River (Marques 1987; Marques and Dias 2003). This concentration has increased

160 from the sixteenth century onward, especially in the Northwest region where cultivation of corn, imported from America, found excellent conditions for development (Ribeiro 1945). It has recently become possible to rigorously confirm this spatial pattern since the beginning of the nineteenth

165 century and quantify its evolution until 1930 (Silveira et al. 2011). In fact, in $1801,46 \%$ of the population lived on that narrow stretch of coastal Portuguese territory. Up until 1864, population distribution remained stable amongst the various regions, but from this moment onward the differences grew,

170 aggravating the structural tendency to densify in the coastal area. The construction of railroads may have contributed to this evolution (Silveira et al. 2011). Following World War II, vigorous emigration as well as migration from rural areas to the city came to strengthen the imbalance in population 175 distribution and accentuate the separation between coastal and inland regions (Ferrão et al. 2005; Rodrigues 2008).

Border studies are currently receiving an increasing attention from researchers from various disciplines. In the case of the Spanish-Portuguese cross-border regions, the inter-

180 est grew especially after the accession of both countries to the EEC, mainly with the aim of counteracting the so-called "historical heritage of the border effect" (Moreira 2001, 7). However, the notion of border, which justifies the perspective of "differentiation, opposition and periphery," commonly

185 used in this case, is a political and historical concept, not a geographical one (Cavaco 1995, 9-10). In fact, it is usually recognized that the Spanish-Portuguese frontier is not a "natural boundary," in most part (Moreira 2001, 8). Some of the references that deal with the border do not have a his-

190 torical depth, focusing their analyses mainly on the period from the 1980s onward, or they address only one segment of the boundary line. Besides, they verified the existence of similar demographic behaviors on both sides of the frontier in the last decades of the twentieth century (Cavaco

195 1973, 1995; López Trigal and Guichard 2000; Moreira 2001; Lois-González 2004; Pires and Pimentel 2004).

Daniel Tirado Fabregat and Marc Badia-Miró (2012) recently argued that these regions were among the poorest of the Peninsula. At the same time, they defended that the bor-

200 der did not break the economic continuity of the zone. This is an important feature to highlight, because it is frequent in the works cited above that the analysis of the border regions is frequently done isolating them from the wider zones to which they belong, thus artificially reinforcing the aforementioned "border effect." This latter article and David Reher's work 205 on Iberian cities (Reher 1994) are among the few that adopt a supranational perspective and are relevant for our purpose.

As this short review suggests, research carried out in Portugal and Spain has been mostly focused on national contexts. It is true that Spanish researchers studied spatial population 210 distribution in Europe in order to find references to understand the history of their own country. However, neither the Spanish researchers nor their Portuguese colleagues have paid much attention to the evolution of the Iberian Peninsula as a whole. Only by understanding the strength of nationalist 215 traditions can we perceive how, both in humanities and in social sciences research as well as in everyday life, it continues to be acceptable to conceive the reality of the two countries independently of one another.

In fact, the two states do share a territory marked by signifi- 220 cant natural contrasts, which nevertheless constitutes a single geographical entity. The border between the two countries is a political construct whose origins lay in the Roman Empire. It was formally established at the end of the thirteenth century (1297) and suffered minor changes in 1801. However, this 225 enduring frontier separates regions with similar geographical characteristics.

The intersection between geographical and political factors creates a challenging setting for research. It stimulates a transnational approach to the study of spatial population 230 distribution in the long run and the re-examination of the importance of natural factors in the explanation of population concentration/dispersion, a topic that has been discussed for a long time, about which more empirical research is needed. In this article, regardless of national frontiers, we will then 235 address the three issues mentioned in the beginning: patterns of spatial population and their historical evolution; the importance of geographical factors to explain population location on the entire Iberian Peninsula; and last but not least, the influence of the Spanish-Portuguese border in population 240 location. The main hypotheses underlying this approach are the following: (a) patterns that have been separately identified in Portugal and in Spain are part of a historical process taking place within the vast peninsular territory regardless of national states; (b) geographical factors had a decisive 245 importance in population location from the beginning of the period analyzed; and (c) that relevance was perpetuated into the second half of the twentieth century.

Bearing in mind the subject of this article and the importance given to geographical factors, we excluded from 250 the analysis the islands and archipelagos belonging to both countries. The period under consideration begins in 1877 for Spain and in 1878 for Portugal and ends in 2001. The definition of the starting years was conditioned by the availability of data. In fact, they correspond to the oldest censuses which 255 provide information on resident population at the municipal level in the Spanish case and the parish level for Portugal. We divided the time span into two periods: 1877/78-1940 and 1940-2001. The turning point corresponds to the 


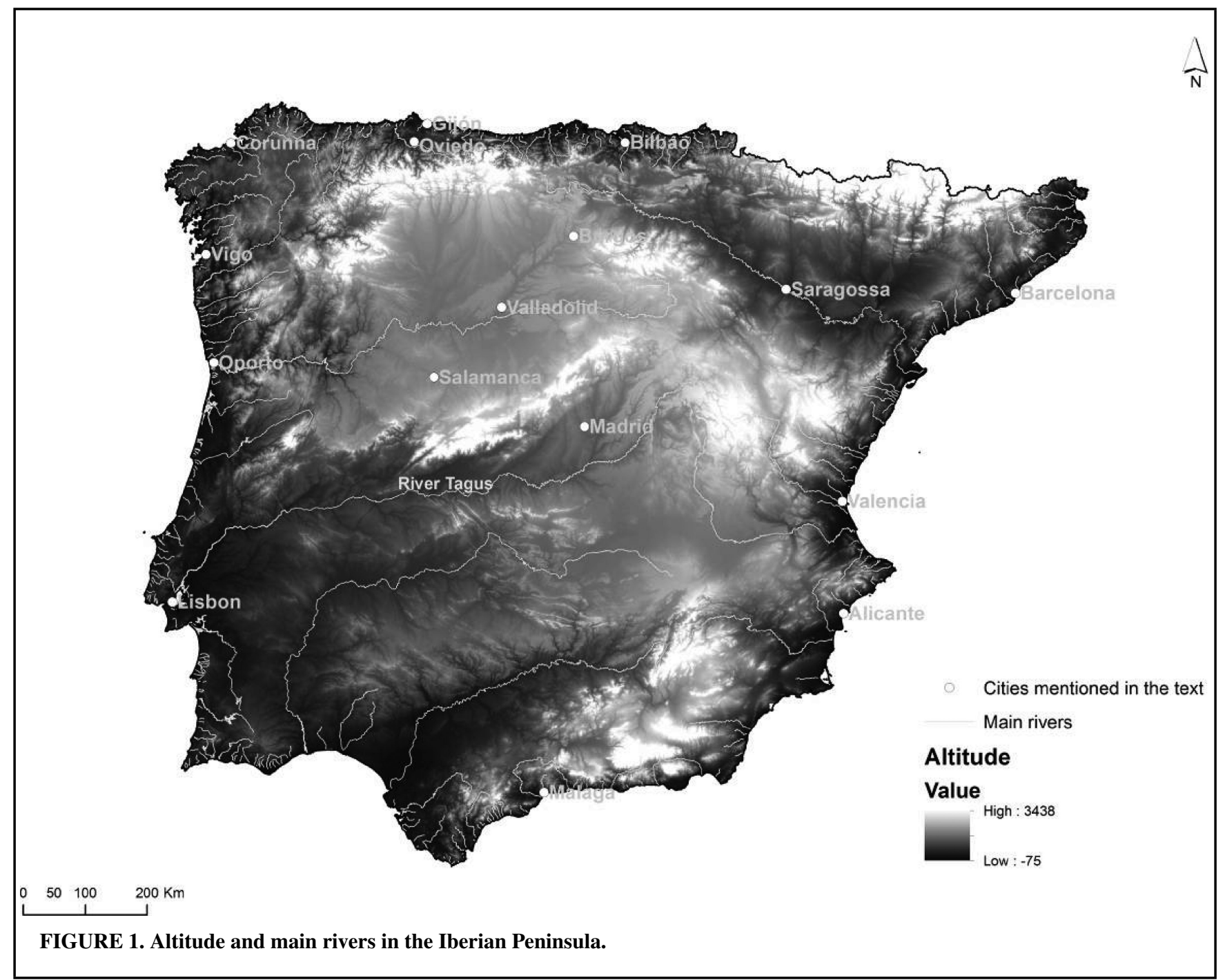

260 beginning of World War II, which separates an era of slow economic growth and limited modernization from the postwar decades filled with rapid economic and social change (Tortella 1994; Carreras and Tafunell 2010; Costa, Lains, and Miranda 2012). Data on population evolution permit other alternatives, either before or after the selected year. However, our choice also had the purpose of creating two periods with a similar duration, comprising minimum number of demographic observations or population censuses. This feature is important for the statistical computations.

\section{Data and Methods}

\section{Data}

We adopted population density as a measure of population concentration and dispersion. As our objective was to analyze the influence of geographical factors, it was apparent that we should work with the greatest detail possible. For this reason, 275 we took Spanish municipalities and Portuguese parishes as our frame of territorial reference. In fact, it is only at this level that certain analyses such as proximity to rivers or the border begin to make sense. Moreover, in this way all the analyses gain rigor. The choice of these territorial parcels obeys yet 280 other criteria which we will present below. One study at this scale has already been undertaken in Spain by Cos Guerra and Reques Velasco (2005) and Goerlich Gisbert and Mas Ivars (2008), but not in Portugal. These authors worked, however, not with density, but with number of inhabitants. We also estimated the trend value of population density in each study period (1877/78-2001; 1877/78-1940; 1940-2001). Population data came from the 13 Portuguese and Spanish censuses carried out from 1877 (Spain) and 1878 (Portugal) up to 2001. Given the availability of a homogenous series of 290 resident population data for the period 1900-2001 in Spain (Goerlich Gisbert and Mas Ivars 2006), we completed that 


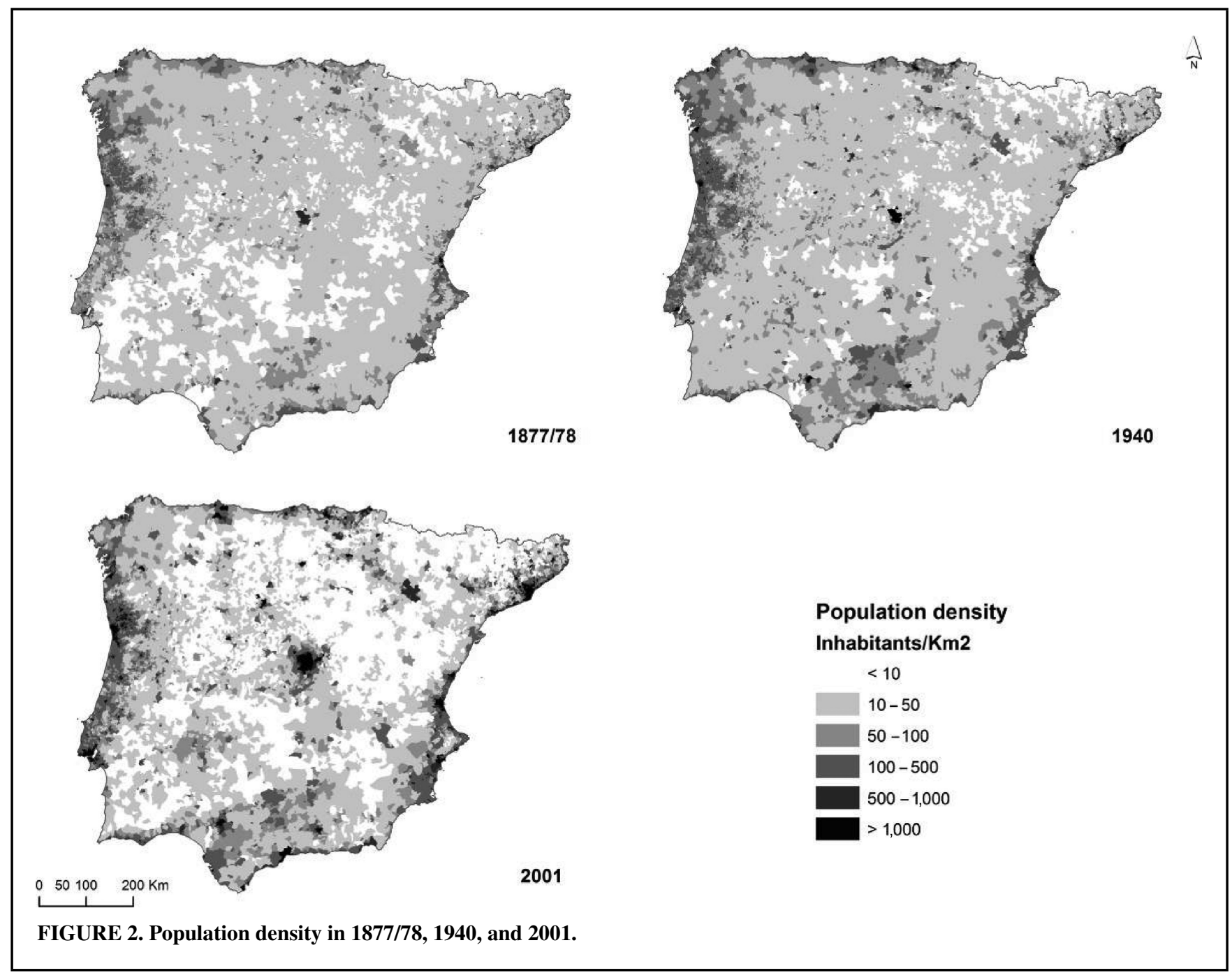

information for the years $1877-1900$ and collected the same variable for Portugal.

In reference to geographical variables, we included altitude, distance to the coast, and rainfall as did the authors cited in our introduction. To these variables we also added average temperature and distance to main rivers, defined as those that flow directly toward the sea. As indicated at the 300 beginning of this article, these factors would decisively influence agricultural productivity, transportation, and access to drinkable water and thus affect population distribution. For reasons previously mentioned, we also analyzed the distance to the border between Portugal and Spain.

305 We took into account the altitude of the local parish and municipal main agglomeration and the average altitude of each of these territories. These data were obtained from a DTM for all the Iberian Peninsula, with a spatial resolution of $200 \mathrm{~m} \times 200 \mathrm{~m}$, constructed for a previous re-

310 search project (Silveira et al. 2011). Distances to the coast, to the main rivers, and to the border were calculated using the central point of the main population agglomeration of each parish/municipality. These points were provided by the Carta Administrativa Oficial de Portugal 2012.1 and, in the case of Spain, by the Nomenclátor Geográfico de Mu- 315 nicípios y Entidades de Población ${ }^{1}$ Precipitation and temperature correspond to the annual recorded average and were obtained from the Digital Climatic Atlas of the Iberian Peninsula (Ninyerola i Casals, Pons, and Roure i Nolla 2005) ${ }^{2}$ These maps also have a spatial resolution of $200 \mathrm{~m} \times 200 \mathrm{~m} 320$ and were generated through spatial interpolation techniques based on monthly and annual precipitation [temperature] series with at least 20 [15] years of data in the period 1950-99 (Ninyerola i Casals, Pons, and Roure i Nolla 2007a, 2007b).

\section{Methods}

The information management and spatial analysis for this project benefited from the work done on the Iberian Peninsula Historical Geographic Information System which began 


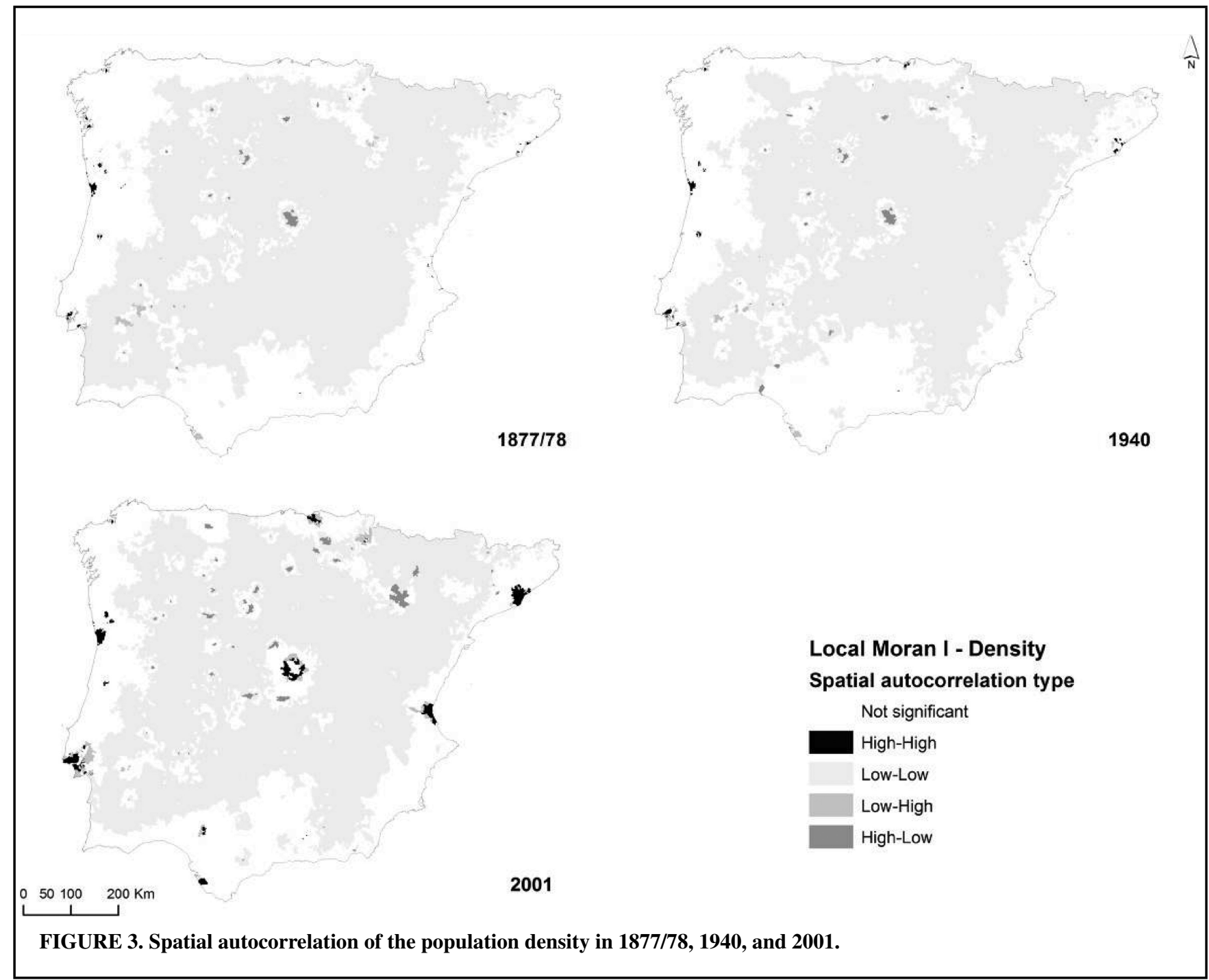

a few years prior. In this system, we merged the base administrative maps of Portugal and Spain for the year 2001. The system also includes the information mentioned in the previous section.

Geographic units and transnational analysis. The analysis of the spatial distribution of a quantitative variable across the territory of two countries requires the adoption of administrative units of similar size. The difficulty is that for the same administrative level, the divisions in Portugal and in Spain were not historically equal in their extension, nor are they currently. From the largest to the smallest, and from the highest political and administrative level to the lowest, there are districts, municipalities, and parishes in Portugal, and autonomous communities, provinces, and municipalities in Spain. The analysis of the average areas of the administrative divisions led us to the conclusion that only the even if they did not occupy the same position in the respective hierarchy.

We finally opted for the latter combination, as these administrative units are the smallest in both countries, allowing not only the in-depth analysis required in this research, but also the reconstitution of higher territorial divisions, thus enabling more aggregate studies. Although seemingly the best approach, this choice does not eliminate differences in extent between Portuguese parishes and Spanish municipalities and their disparity across the Peninsula from North to South, which can be clearly seen on a map. These differences affect the maps which represent population density and introduce some bias into quantitative analysis.

Data interpolation. To overcome the problems caused by the changes in territorial units over time, data on resident population from both countries were interpolated into a 2001 map. In the Spanish case this was done "manually," without any GIS, and the reconstitution of the historical population of 


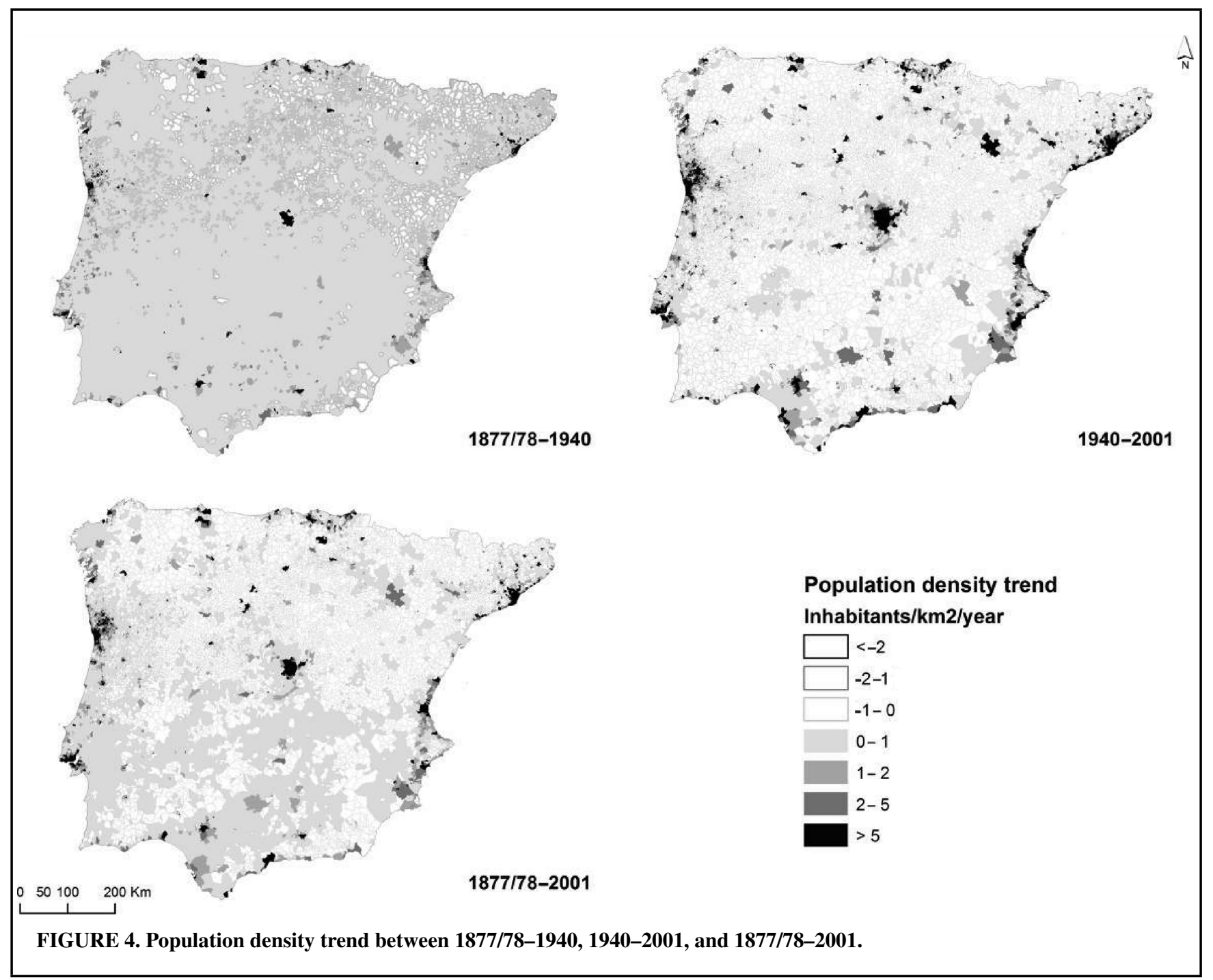

a 2001 municipality was based on the information regarding population settlements included in its territory in 2001 provided by the previous censuses (Goerlich Gisbert and Mas Ivars 2006). Regarding Portugal, two geographic data interpolation methods, previously tested in an earlier work, were the areal-weighting interpolation in urban areas, currently used in this type of studies (Gregory and Ell 2007), and a second method, using the distribution of population in the parishes during the target year (2001) as simplified ancillary data in the interpolation process ${ }^{3}$ In any case, the overwhelming majority of the Portuguese population from the distinct censuses were not affected by the interpolation process since the parishes in which they lived did not undergo any boundary changes (Silveira et al. 2011).

Local spatial autocorrelation. The local version of 380 Moran's I, which is a measure of spatial autocorrelation, can be used to identify local spatial clusters and spatial outliers (Anselin 1995). The cluster maps depict locations classified by type of association, with significant (5\% level) Local Moran statistics. The locations classified as "highhigh" and "low-low" suggest clustering of similar values (positive local spatial autocorrelation) and correspond to parishes/municipalities with high [low] values that are surrounded by parishes/municipalities with high [low] values. The "high-low" and "low-high" locations are termed "spatial outliers" (negative local spatial autocorrelation), 390 corresponding to parishes and municipalities with values that are significantly different to those of their nearest neighbors.

The computation of the Local Moran I statistic requires conceptualizing the spatial relationship between parishes/ 395 municipalities, which was done by using a criterion known as second order queen contiguity. The first order criterion establishes that only neighboring parishes/municipalities that share a boundary will influence computations for the target parish/municipality. The second order criterion 
TABLE 1. Distribution of the Population According to the Density Trend (1877/78-2001)

\begin{tabular}{|c|c|c|c|c|c|c|}
\hline & Decreasing & Not significant & Increasing & $\begin{array}{c}\text { Decreasing } \\
(\%)\end{array}$ & $\begin{array}{c}\text { Not significant } \\
(\%)\end{array}$ & Increasing $(\%)$ \\
\hline Parishes/Municipalities & 3,777 & 4,977 & 3,376 & 31.1 & 41.0 & 27.8 \\
\hline \multirow[t]{2}{*}{$\mathrm{Km}^{2}$} & $163,855.6$ & $267,947.9$ & $153,139.3$ & 28.0 & 45.8 & 26.2 \\
\hline & \multicolumn{3}{|c|}{ Inhabitants } & \multicolumn{3}{|c|}{$\%$ Inhabitants } \\
\hline $\begin{array}{l}\text { Years } \\
1878\end{array}$ & $4,439,352$ & $6,902,807$ & $9,071,866$ & 21.7 & 33.8 & 44.4 \\
\hline 1890 & $4,486,029$ & $7,367,826$ & $9,863,272$ & 20.7 & 33.9 & 45.4 \\
\hline 1900 & $4,450,460$ & $7,809,825$ & $10,877,361$ & 19.2 & 33.8 & 47.0 \\
\hline 1911 & $4,532,551$ & $8,493,770$ & $12,038,001$ & 18.1 & 33.9 & 48.0 \\
\hline 1920 & $4,408,565$ & $8,884,265$ & $13,458,811$ & 16.5 & 33.2 & 50.3 \\
\hline 1930 & $4,254,425$ & $9,476,823$ & $15,562,867$ & 14.5 & 32.4 & 53.1 \\
\hline 1940 & $4,114,707$ & $10,061,818$ & $18,157,564$ & 12.7 & 31.1 & 56.2 \\
\hline 1950 & $3,902,001$ & $10,284,882$ & $20,544,381$ & 11.2 & 29.6 & 59.2 \\
\hline 1960 & $3,480,566$ & $9,813,573$ & $24,224,925$ & 9.3 & 26.2 & 64.6 \\
\hline 1970 & $2,671,223$ & $7,927,059$ & $29,735,724$ & 6.6 & 19.7 & 73.7 \\
\hline 1981 & $2,200,616$ & $7,024,260$ & $35,656,603$ & 4.9 & 15.7 & 79.4 \\
\hline 1991 & $1,931,538$ & $6,486,119$ & $37,503,515$ & 4.2 & 14.1 & 81.7 \\
\hline 2001 & $1,785,662$ & $6,262,745$ & $39,994,245$ & 3.7 & 13.0 & 83.2 \\
\hline
\end{tabular}

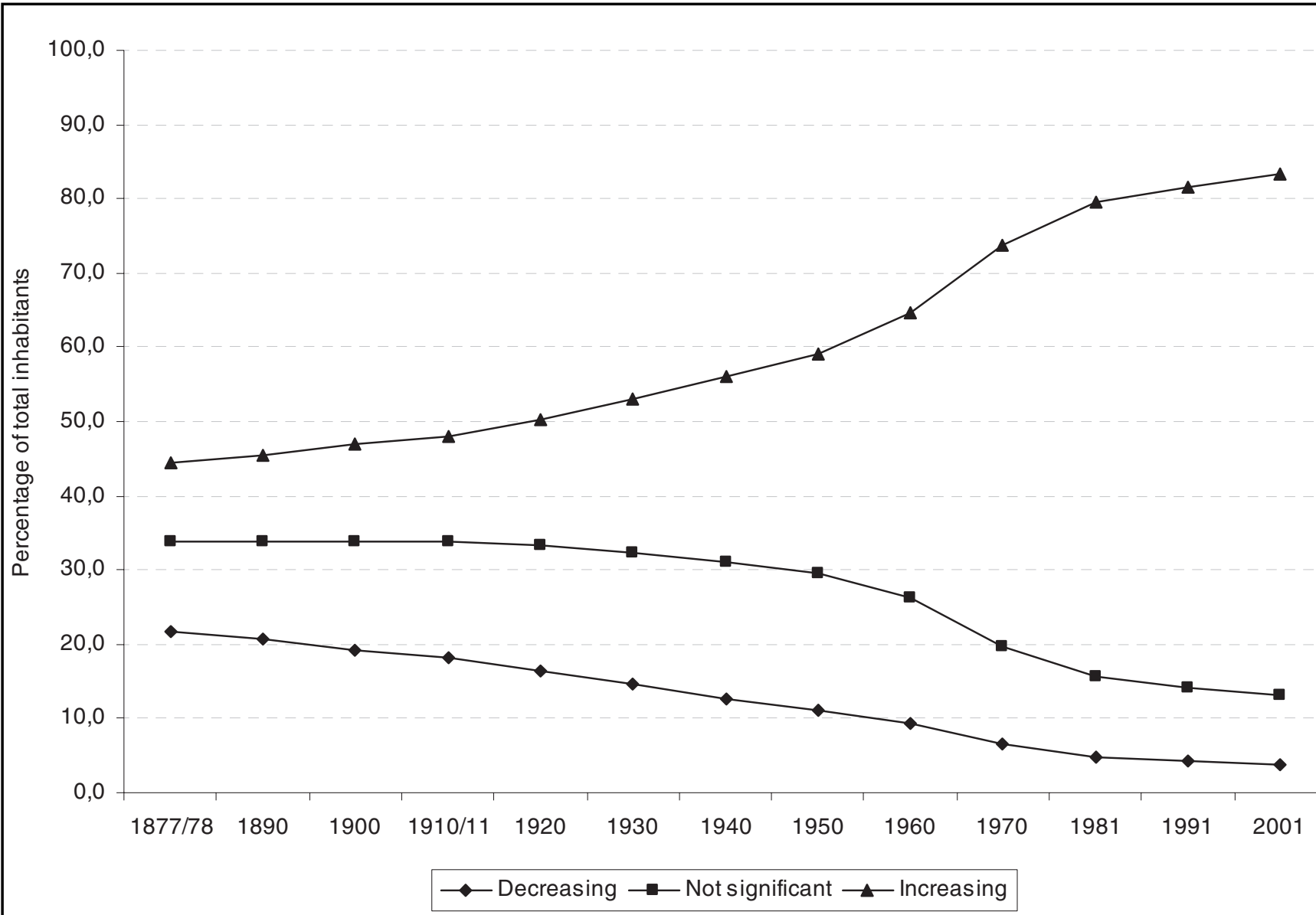

FIGURE 5. Distribution of the population according to the density trend (1877/78-2001). 
TABLE 2. Association Between the Population Density in the Starting and Ending Year of Each Study Period, Measured by the Spearman's Correlation Coefficient (R)

\begin{tabular}{lcc}
\hline \hline Study period & $\mathrm{R}$ & $p$ value \\
\hline From 1877/78 to 1940 & 0.9305 & .0000 \\
From 1940 to 2001 & 0.9117 & .0000 \\
From 1877/78 to 2001 & 0.8292 & .0000 \\
\hline
\end{tabular}

extends this group to include the neighbors of the first order neighbors.

Trend assessment. The computation of the trend magnitude of population density as well as the assessment of its statistical significance (5\% level) were applied to each parish/municipality data of the following study periods: (a) 1877/78-2001; (b) 1877/78-1940; and (c) 1940-2001. A nonparametric approach is preferred over the traditional regression analysis because of the violation of its 410 assumptions, particularly the homoscedasticity of the errors and the regularity of error distribution. In fact, many parishes/municipalities exhibit heteroscedastic errors (not shown), which make the statistical tests unreliable. Moreover, violations of normality compromise the estimation of coefficients and the assessment of trend significance.

The nonparametric estimator proposed by Pranab Kumar Sen (1968) was used to compute the trend magnitude for each parish and municipality within the study periods considered. To test the null hypothesis of no trend, the well-known nonparametric Mann-Kendall test (Mann 1945; Kendall 1975) was applied to each set of parish/municipality data, for each of the study periods considered. The $p$ values of each test location and period correspond to the smallest level of significance, leading to the rejection of the null hypothesis within dence of trend for $p$ values exceeding .05.

Analysis of association with geographical attributes. Considering that the assumptions of the Pearson's correlation test are violated, the nonparametric Spearman's test was applied to assess the association between population variables and 430 the above mentioned geographical attributes. The population variables correspond to the population density of each year, and the trend magnitude of each study period (1877/78-2001; 1877/78-1940; 1940-2001). The 5\% significance level was considered to test the null hypothesis of no association be- 435 tween two variables. Amongst the geographical attributes that are significantly associated with the population variables, an especial attention was given to those having a Spearman's correlation coefficient greater [smaller] than $0.4[-0.4]$.

The Iberian Peninsula might have sub-regions where pop- 440 ulation had distinct behaviors throughout the years that may cancel out the effect of association with the geographical attributes. Therefore, in order to further understand the relationship between population evolution and geographical factors, the Iberian Peninsula was stratified into one 445 of three different ways, depending on the trend results of the 1877/78-2001, 1877/78-1940, and 1940-2001 periods. Hence, the methodological framework was applied separately to each stratum of these three time periods. For each of the latter, a parish/municipality was assigned to stratum 1 if 450 its population density decreased; it was assigned to stratum 2 if there was no significant trend; and it was assigned to stratum 3 if its population density increased in the corresponding period.

Results

\section{Spatial Distribution Patterns and Their Evolution}

To characterize spatial distribution of population density and its evolution on the Iberian Peninsula as a whole over 120 years, we will proceed with an analysis structured in three successive and complementary steps. In this way, be- 460 yond a geographical description of population density at three

TABLE 3. Association Between Population Density and Geographical Factors, Measured by the Spearman's Correlation Coefficient (R)

\begin{tabular}{|c|c|c|c|c|c|c|c|c|c|c|c|c|c|}
\hline Variable & $1877 / 78$ & 1890 & 1900 & 1910/11 & 1920 & 1930 & 1940 & 1950 & 1960 & 1970 & 1981 & 1991 & 2001 \\
\hline Temp & & 0.408 & 0.425 & 0.449 & 0.470 & & & & & & & 0.569 & 0.576 \\
\hline Precipitation & & 0.39 & 0.396 & 0.3 & 0.3 & 0.3 & & & & & & 0.362 & 0.342 \\
\hline Altitude & 76 & -0.589 & -0.600 & -0.615 & -0.630 & -0.640 & -0.651 & -0.655 & -0.665 & -0.682 & -0.703 & & -0 . \\
\hline $\begin{array}{l}\text { Distance to } \\
\text { littoral }\end{array}$ & -0.585 & -0.576 & -0.573 & -0.571 & -0.577 & -0.569 & -0.566 & -0.555 & -0.553 & -0.575 & & -0.588 & -0.588 \\
\hline $\begin{array}{l}\text { Distance to } \\
\text { main rivers }\end{array}$ & -0.487 & -0.483 & -0.485 & -0.486 & -0.493 & -0.492 & -0.490 & -0.488 & -0.490 & -0.501 & -0.507 & -0.510 & -0.510 \\
\hline $\begin{array}{l}\text { Distance to } \\
\text { PT/ES border }\end{array}$ & -0.177 & -0.197 & -0.209 & -0.213 & -0.199 & -0.211 & -0.250 & -0.273 & -0.274 & -0.233 & -0.231 & -0.206 & -0.170 \\
\hline
\end{tabular}




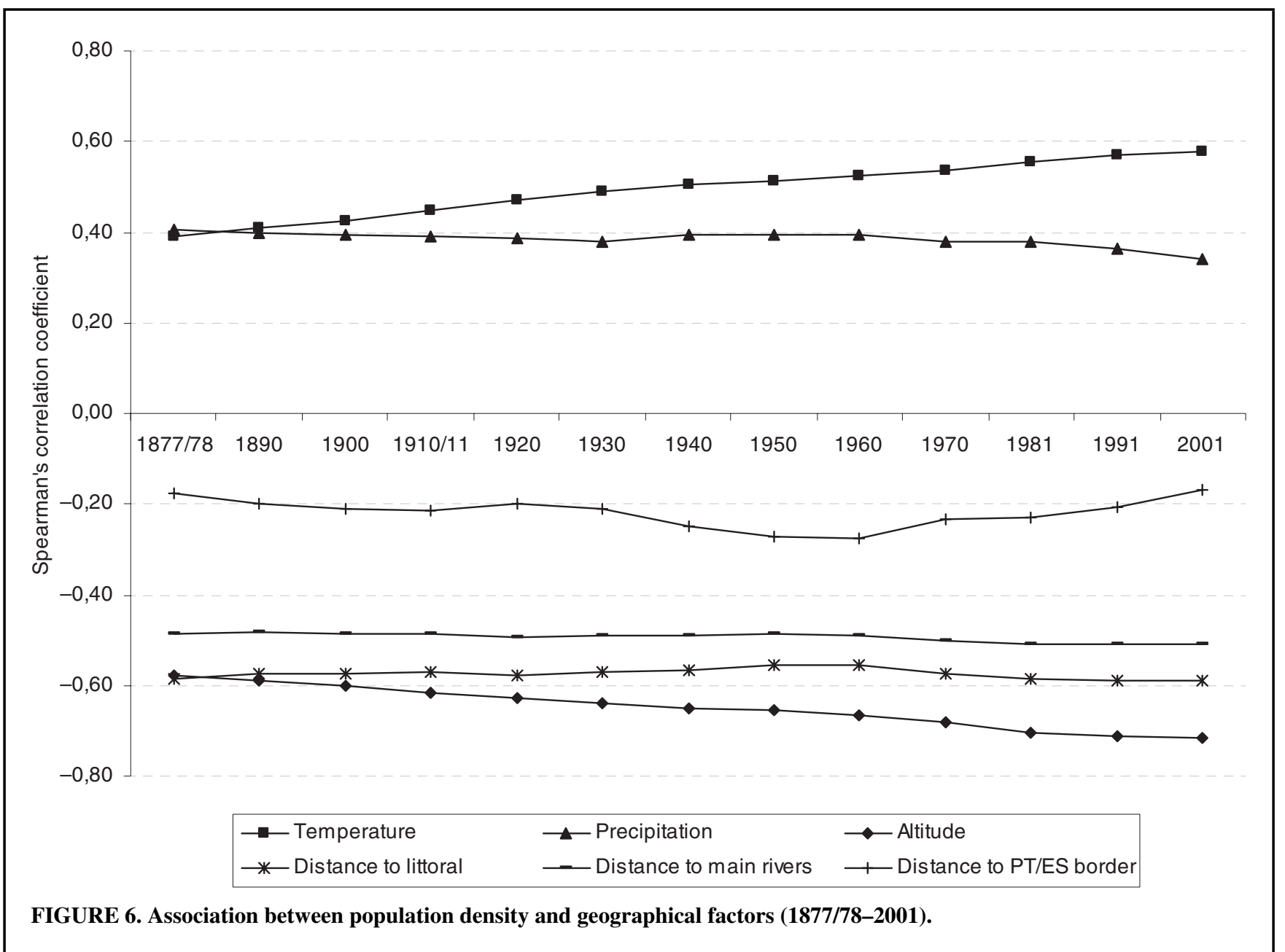

identified moments in time, 1877/78, 1940, and 2001, we also seek to understand how each parish/municipality related to neighboring territories as a manner of identifying the autocorrelation patterns of this variable and, ultimately, analyse its evolutionary trends. See Figure 1.

Figure 2 shows population density at those three moments. In all maps, we have deliberately erased the frontier between the two countries. As we can observe, in $1877 / 78$ population 470 was already concentrated, to some degree, in the coastal regions. We notice a large area extending from Southern Portugal, passing through the Spanish Southern Plateau, and ending at the Pyrenees, with very small density rates. In the center of the Peninsula, between areas of high and medium density,

475 Madrid stands out. In 1940, population densities increased almost everywhere with the exception of the region closest to the Pyrenees and a small area to the South of the Sistema Central, without breaking the general pattern. The growing density on the coastal stretch from Corunna to Lisbon should inland areas. However, the big change occurs passing from 1940 to 2001, reflecting the process of economic expansion

following the war and the industrialization and urbanization movements associated with it. In this regard, the 1970s were a dramatic period of change. The contrasts between rural and 485 urban regions and between inland and coastal regions became sharper than ever. During the 1980s and the 1990s, the depopulation of rural areas continued as metropolitan zones expanded.

On all these maps it is visually impossible to distinguish 490 Portugal from Spain. The concentration of population on the Atlantic coast to the North of the Tagus River continues into Galicia in Spain and forms the largest continuous high density area on the Peninsula. Similar trends seem to affect crossborder regions and rural and urban zones in both countries.

The goal of our next step was to confirm spatial population density patterns suggested by previous analysis. Focusing on population density in the three years mentioned, we calculated the Local Moran Indicator to test the spatial autocorrelation of this variable (Figure 3 ). The $1877 / 78$ map displays a 500 large inland area of the Peninsula dominated by low density clusters. In the South of Portugal, this area reaches to the Atlantic Coast. The map also pinpoints some high density 
TABLE 4. Association Between Density Trend Magnitude and Geographical Factors, Measured by the Spearman's Correlation Coefficient $(\mathbf{R})$

\begin{tabular}{|c|c|c|c|c|c|c|}
\hline \multirow[b]{3}{*}{ Variable } & \multicolumn{6}{|c|}{ Population density trend magnitude } \\
\hline & \multicolumn{2}{|c|}{$1877 / 78-2001$} & \multicolumn{2}{|c|}{$1877 / 78-1940$} & \multicolumn{2}{|c|}{ 1940-2001 } \\
\hline & $\mathrm{R}$ & $p$ value & $\mathrm{R}$ & $p$ value & $\mathrm{R}$ & $p$ value \\
\hline Temperature & 0.4161 & .0000 & 0.4676 & .0000 & 0.2026 & .0000 \\
\hline Precipitation & 0.1698 & .0000 & 0.2160 & .0000 & 0.0098 & .2814 \\
\hline Altitude & -0.4754 & .0000 & -0.5012 & .0000 & -0.2787 & .0000 \\
\hline Distance to littoral & -0.3289 & .0000 & -0.3043 & .0000 & -0.2655 & .0000 \\
\hline Distance to main rivers & -0.2777 & .0000 & -0.2844 & .0000 & -0.1891 & .0000 \\
\hline $\begin{array}{l}\text { Distance to } \\
\text { Portugal/Spain border }\end{array}$ & -0.1033 & .0000 & -0.2401 & .0000 & 0.1932 & .0000 \\
\hline
\end{tabular}

clusters, corresponding to urban areas, on the Western Atlantic strip such as Lisbon, Oporto, Vigo, and Corunna as well as on the Spanish Mediterranean Coast such as Barcelona and Valencia. Cities that stand out within the interior of the Peninsula are few, seemingly concentrating themselves in the Northern part and characterized by a negative spatial autocorrelation, combining the high density of the city core with the low density of the surrounding municipalities, as in the cases of Valladolid and Burgos, but especially Madrid. This general pattern is virtually unchanged when we observe the Local Moran Indicator map in 1940. In 2001, the most re- clusters. They correspond to a large share of the most populated urban centers of the Peninsula. The two major cities in the coastal region of both countries (Barcelona and Valencia in Spain; Lisbon and Oporto in Portugal) really stand out, with a pattern that clearly shows the process of suburbanization that affected these centers in the last decades of the twentieth century. The same can be said of Madrid, with the characteristic emptying of the city center being here that much more visible still. Beyond this, the pattern of an ample zone filled with low densities continues throughout 525 the interior of the Peninsula, spreading itself now to include a substantial part of Galicia and of the Northern interior of Portugal.

To characterize the evolution of population density and of the spatial patterns described above, we calculated the 530 density growth trend in the general period and in the two 
TABLE 6. Association Between Population Density and Distance to the Frontier in the Spanish-Portuguese Border Region (NUTS III), Measured by the Spearman's Correlation Coefficient $(\mathbf{R})$

\begin{tabular}{lcc}
\hline \hline Density & $\mathrm{R}$ & $p$ value \\
\hline $1877 / 78$ & -0.0897 & .0000 \\
1940 & -0.0339 & .0584 \\
2001 & -0.0069 & .7012 \\
Density trend & & \\
$1877 / 78-1940$ & 0.0987 & .0000 \\
$1940-2001$ & 0.0642 & .0003 \\
$1877 / 78-2001$ & 0.0507 & .0047 \\
\hline
\end{tabular}

sub-periods, 1877/78-1940 and 1940-2001 (Figure 4). The trend between $1877 / 78$ and 2001 emphasizes the strong growth of the big coastal urban agglomerations as well as of the inland middle-size cities. The map also pictures a certain distinction between the positive evolution of the region South of the Tagus river and opposite trend of the area on the North of the same river. In the first period, it is clear that the urban areas, especially in the coastal regions, were already growing faster, followed by the city of Madrid. The decrease of densities, mainly in values that stay below one inhabitant per $\mathrm{km}^{2}$ per year, is visible in the Northern part of the Peninsula, tending to affect larger areas in the Northeast and some municipalities along the Spanish Mediterranean coast. In the rest of the Peninsula, the population density is growing. The map of the period between 1940 and 2001 depicts the divide between the inland and the coastal periphery, the former with general negative growth values, punctuated by several "small islands." These ones represent population growth in

550 urban areas surrounded by zones of rural depopulation. The exceptional growth of Madrid and its suburbs stands out. A vigorous upward movement in an almost continuous coastal line surrounding the Peninsula is also noticeable, with the exception of a small part of the Southwest coast of Portugal 555 and of the Cantabrian coast.

At the base of this analysis are three strong long-term trends in population distribution that can be pointed out on the Iberian Peninsula: population concentration on the coast to the detriment of the interior (even taking into account the

560 exceptions previously noted); a more pronounced concentration in the big cities (also, overwhelmingly, situated on the coast and representing a larger population than all the other areas combined); and, finally, a certain contrast between the Northern Peninsula which, globally, seems to lose its pop-

565 ulation density, and the Southern Peninsula, which, also in general terms, is witnessing an increase in this demographic variable.

Table 1 and Figure 5 help us to understand the evolution that has been described so far. The territories with signifi- cant trends represented 54\% of the Peninsula's area, divided 570 relatively equally between growth zones and those that lost population. Despite this territorial equilibrium, one observes an accentuated difference in population distribution in these zones in $1877 / 78$. In fact, the parishes and municipalities that were to grow in the period under observation already 575 had twice the resident population that existed in the zones that were to experience a decrease. The changes registered up to 2001 greatly aggravate this inequality and lead to a situation in which more than $80 \%$ of the population would come to be concentrated within merely $26 \%$ of the Penin- 580 sula's territory. At the opposite end of the spectrum, in 2001 the resident population of areas that lost inhabitants (close to 1.8 million), in comparison, would be little more than the number of residents in the municipality of Barcelona (close to 1.5 million), living in $27 \%$ of the Peninsula's territory.

In the zones with a trend of increasing population density, we pinpoint two distinct moments of acceleration in this process: passing from 1910/11 to 1920 and, in an even more sharply accentuated way, from 1950 to 1960 (Table 1 and Figure 5). It is notable that in 1920 the population concentrated in these areas already represented $50 \%$ of the total population. Analyzing absolute resident population values, the turning point at the middle of the twentieth century is reconfirmed. In fact, until 1950 one sees an incremental population increase in $75 \%$ of the Peninsula's area (corresponding 595 to the zones that always grew and to those with a no significant trend, but which did effectively grew until 1940/1950), while after that date population growth would be restricted to little more than $25 \%$ of the Peninsula's territory.

Observing population density trend in the period 600 1877/78-2001 (Figure 4), we already verified that the areas with strong growth corresponded to the large urban agglomerations along the coast, such as Barcelona, Valencia, Alicante, Malaga, Lisbon, Oporto, Vigo, Corunna, Gijón, and Oviedo e Bilbao (each with more than 200,000 residents 605 in 2001), as well as Madrid, obviously, and a small number of medium-sized cities in the interior such as Saragossa, Valladolid, Burgos, and Salamanca (each with more than 150,000 residents in 2001). This is something also visible and consistent with the spatial autocorrelation map of 2001 (Figure 3). Looking at Figure 4, we also pointed to a particular difference between North and South (regions divided by the Tagus River). In the North of the Peninsula, polygons corresponding to the parishes and municipalities that registered a trend of population decrease were (in number) $30 \% \quad 615$ more and (in area) more than double of those that grew. This perspective is reversed in the South of the Peninsula where the parishes and municipalities that grew in density represent more than double in number and almost five times the area of those that experienced a decrease.

By observing the absolute values in Table 1, the graph in Figure 5, and the correlations coefficients in Table 2, it is possible to move forward with one hypothesis in order to explain the spatial distribution and trends described above. 


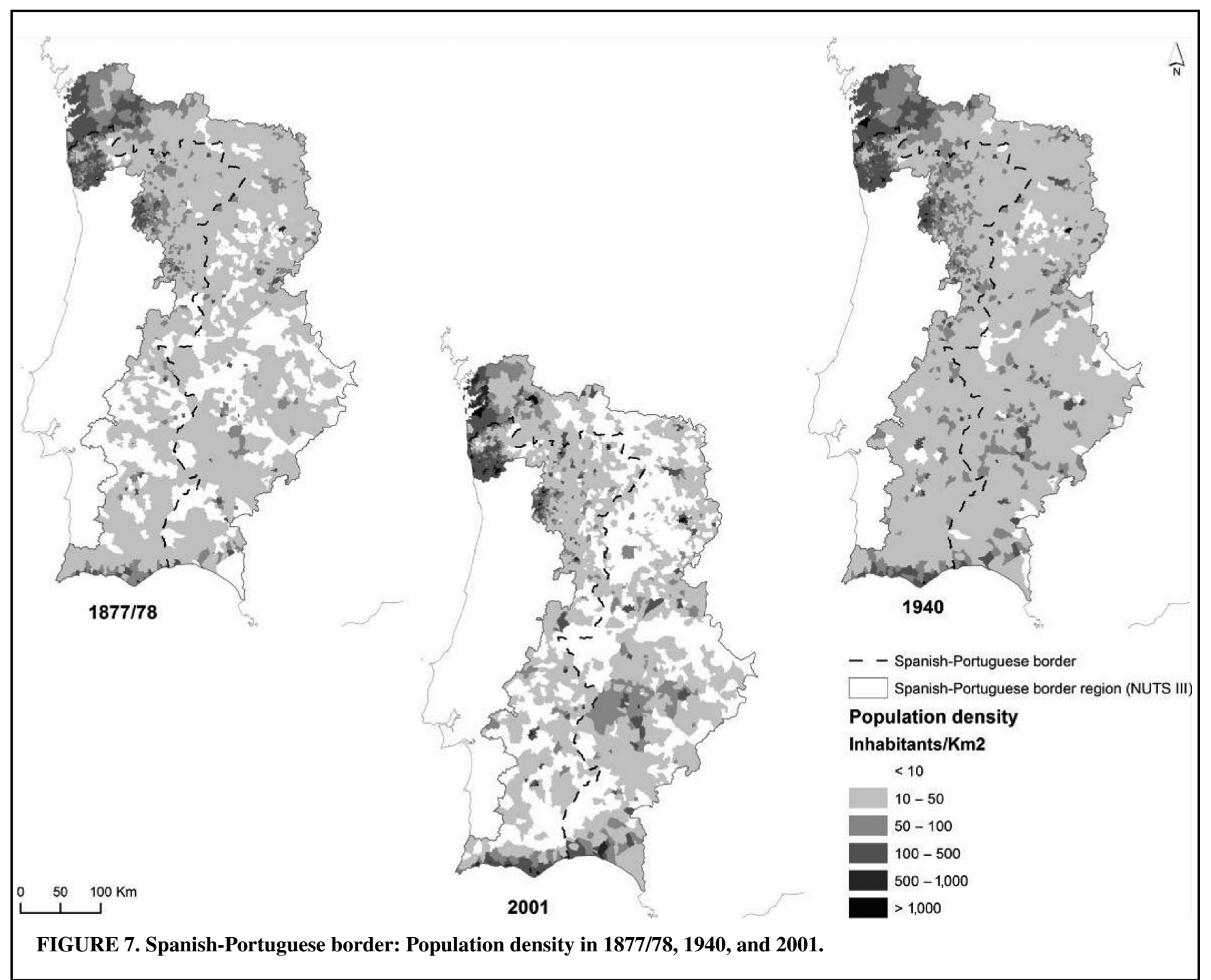

The first fact to note is that globally, given the value of the Spearman coefficient, the relative position of the parishes and municipalities in $1877 / 78$ is very close to that in 2001 . This solidifies the idea expressed in the introduction, now extended to the whole of the Peninsula, at the lowest administrative level of the two countries, in which a significant part of populational attraction, measured by the evolution of the trend of population density, results from a self-sustained process. This means that the agglomerations of the nineteenth century that managed to capture a greater volume of the pop635 ulation are going to be, by this fact and by the dynamics of subsequent political, social, and economic developments, the principal targets of internal migration flows that will, in turn, strengthen and self-nourish a previously visible trend.

In second place, it is obvious that this process was only 640 partially fed by the parishes and municipalities in which the population presented a downward trend. In these cases, there is a visible and almost linear evolution, and the number of inhabitants involved is relatively small (Table 1 and Figure 5). If it is certain that in absolute terms 1910/11 coincides with the year in which these territories begin to lose population 645 in a continuing pattern, it is all the more relevant to observe that the year 1950 represents the same phenomenon in areas with no defined trend. If we pay attention to the fact that the population in these last areas grew from 7 million to almost 10 million residents between $1877 / 78$ and 1950 and then 650 decreased continuously and sharply until 2001 to numbers inferior to initial figures, we understand that essentially, it was here that the previously mentioned gap widened.

\section{Association With Geographical Factors}

In the analysis of the relationship between geographical 655 factors and population density values, practically all exercises resulted in statistically significant coefficients for almost all variables and for each observed moment. Seeking 


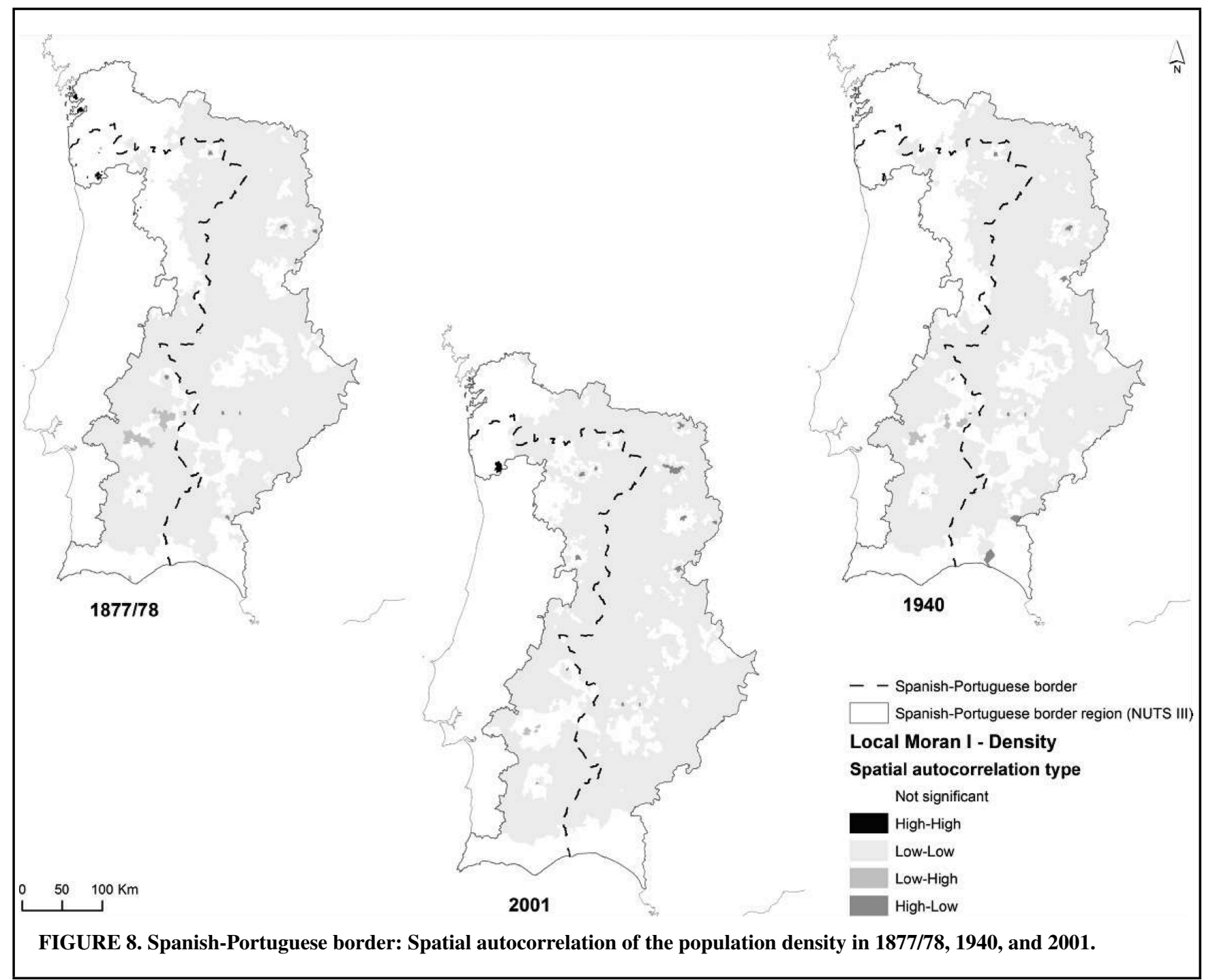

to highlight factors with the greatest intensity of association

with spatial distribution of the Iberian Peninsula's population, we selected only the Spearman coefficients with values that were equal to or surpassed $0.4(-0.4)$, with two exceptions. The altitude of the parish and municipal main agglomeration was not used as it was apparent that working with territorial divisions of such small scale, the value of the coefficients reflected almost perfectly the average altitude of the polygon, which made its use redundant. In the case of distance to the border, since it would correspond to one of this study's central questions, we considered its analysis pertinent, despite those values being below the indicated limit (Table 3).

Observing Table 3 and Figure 6, we can highlight the importance of median altitude and distance from the shore in the relationship to spatial distribution of the population between $1877 / 78$ and 2001. Aside from presenting slightly lower coefficient values, distance to main rivers is equally relevant. These data lead to the characterization of population distri- bution in $1877 / 78$ as one of a population with the tendency to concentrate in regions of lower altitude, close to the shore and to the main rivers. Despite noting a certain stability and 680 persistence in the level of association between these factors and the various moments of observing population density, in the case of altitude one sees a progressive and notable building up in the intensity of this relationship throughout the entire period under study, being the only variable to pass the barrier of 0.7 on a scale that oscillates between 0 (no association) and 1 (perfect association).

In factors related to climate, the relationship with the distribution of population density is relatively stable in the case of rainfall, falling slightly in the last observed years. Regarding average temperature, which in the data of the first two censuses had values closely resembling those of rainfall, one notes an evolution very similar to that detected for median altitude, with a notable increase of intensity in this relationship as time goes on. Generally, one could say that population 695 density tended to be greater in regions with a higher annual 


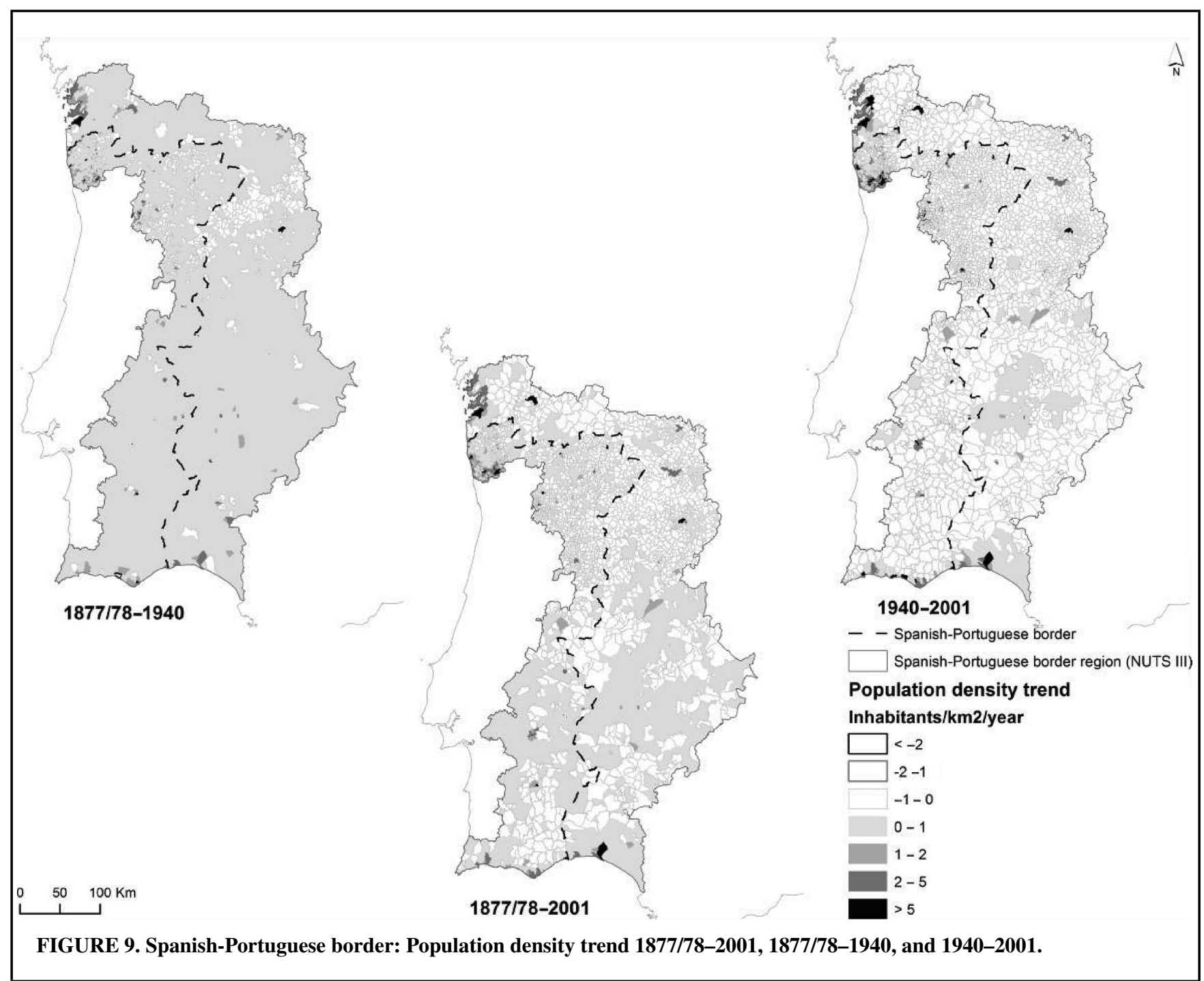

average temperature. Although less visible comparing the first year and the final year, the relationship of higher population density with greater rainfall begins to lose intensity beginning in the middle of the twentieth century.

As we observed the density map for $1877 / 78$, we had already pointed out a strong tendency for a greater population concentration in coastal regions which, basically, were also the lower-altitude regions and those which had a denser hydrographic network (Figures 1 and 2). The simultaneous presence of these three factors seems to have determined from very early population distribution on the Iberian Peninsula with few exceptions, amongst them Madrid and a handful of medium-sized cities in the interior of the Peninsula.

If it is possible to verify the always statistically significant and intense association between geographical factors and density in each year, when we look at the relationship of the same factors with population density trends, the first conclusion we come to is that in the global period, the associations are on average less intense, only revealing themselves to be relevant (equal or greater than $0.4[-0.4]$ ) in regards to altitude and average temperatures (Table 4). This intensity diminishes in reference to distance to the coast and even more so with respect to distance to main rivers. Despite the differences in the levels of intensity of the associations, the relationship between various geographical factors and population density trend is similar to that which has already been observed about spatial distribution pattern. It can be affirmed that in general terms, a stronger trend in population density growth is somehow associated with geographical locations that are characterized by simultaneously having a higher average temperature, a lower median altitude, and greater proximity to the coast and main rivers. Association with average rainfall presents values substantially lower than other factors.

It is important to point out that all variables present sub- 730 stantially different behaviors when their intensities are compared within each one of the sub-periods. Without exception, all present a greater intensity of association with density trends during the period 1877/78-1940 than in the following 
period in which Spearman values all drop in a significant way, in some cases to less than half, becoming statistically not significant as in the case of rainfall (Table 4). This is consistent with the idea that geographical factors, despite continuing to have importance in spatial population distribu-

740 tion in the second half of the twentieth century, lose weight in the explanation of this evolution. This fact would be related with the self-sustaining and cumulative character of population growth previously referred to. Highlighting once again the most relevant intensities of association, perhaps

745 one could assert that between 1877/78 and 1940 the evolution of population distribution was somehow influenced by median altitude and average temperature of the parishes and municipalities, but these factors did not have the same relevance in changes occurring in population density in the 750 period 1940-2001.

In part, we deem that the singular evolution experienced by those areas with a statistically not significant evolution in population trends, to which we have previously referred, could be an explanation for differentiated trends in both sub-

755 periods, once combined with associations to geographical factors. In a primary phase, population increases even in areas where average altitude surpasses 600 meters (Figures 2 and 4), corresponding roughly to the Northern Plateau, the Southern Plateau, and to the Sistema Central and Ibérico,

760 characterized by high plains and some ranges, despite the same occurences on the plains of Alentejo and Andalusia. In a second moment, these same areas lose population amidst a quickening rhythm of population concentration along the coast and in some cities in the interior of the Peninsula

765 (Figures 2 and 3).

Simultaneously, if we focus on the areas with positive and negative general trends (Table 5), we see that the parishes and municipalities that are growing have an association with geographical factors, in particular to those which pertain to

770 altitude and distance from the coast, which are more intense in the first period than in the second, and that this evolution is inverted in the case of parishes and municipalities that see their population density decrease in general with more intense associations in the second period than in the first.

775 This is a finding that is in line with that which was observed in the temporal evolution of population indicators (Table 1 and Figure 5), seemingly pointing to a greater influence of geographical factors as factors for attracting population until the middle of the twentieth century, becoming in the second

780 half of the century factors of repulsion in zones which are losing population on the Iberian Peninsula.

\section{The (Ir)relevance of the Border}

As previously observed, associations of spatial distribution of population density within each one of the observed moments with the distance from the Spanish-Portuguese border correspond to the least intense of all variables selected for this study, oscillating between a maximum of -0.27 and a minimum of -0.17 (Table 3 ). However, it is necessary to mention that these calculations are clearly influenced by the inclusion of all the territory of the Iberian Peninsula. Distortions are introduced into the analysis not only because the lesser distance between the coast and the border in the Portuguese case increases population concentration values which are taken into account in the association with proximity to the border, but also due to the reverse phenomenon when one includes very distant regions in the analysis, such as Saragossa and Barcelona also characterized by a high density.

Therefore, we had to devise a way to isolate the effect of the frontier on the Spearman coefficient calculations. It is 800 difficult to delimit cross-border regions based on such small size units as parishes and municipalities. The combination of Portuguese districts and Spanish provinces was not an alternative, since the use of the former would entail the inclusion of areas far away from the frontier. The most satisfactory 805 solution to overcome these problems seemed the adoption of the NUTS III existing in 2001, which in Spain correspond to the provinces and in Portugal to units smaller than the districts. After defining the area to be analyzed, we took into consideration the parishes and municipalities contained in 810 those divisions and recalculated all the Spearman's coefficients (Table 6).

The first conclusion to be drawn is that the weak association between distribution of population density and distance to the border when considering the whole Peninsula became 815 practically non-existent when we narrow our attention on the border region. All Spearman's values come very close to zero, falling over time and, in the case of associations with density in 1940 and 2001, resulting in statistically not significant values. In the case of trends, whether general or those of 820 the sub-periods, they prove to be equally very weak, always inferior to 0.10 (Table 6).

These observations support the hypothesis that proximity to the border did not generate any distinct pattern in population density, whether in terms of spatial distribution or in the temporal evolution. Basically, it was the fact of being near or far from the coast, of having high or low altitude, or of being distant or close to the rivers that influenced values of population density in this region.

Observation in greater detail of the density distribution, 830 spatial autocorrelation, and trend maps, now with the boundary line drawn (Figures 7, 8, and 9), allows for the verification of three relevant aspects of this "porous demographic" Spanish-Portuguese border. On one hand, the border zone is not uniform when it comes to population distribution, quite 835 the opposite. We are not talking about a single border region but more realistically about three distinct regions, encompassing the Northern coastal area between Galicia and Minho, the central interior that goes from the districts of Vila Real to Beja on the Portuguese side and the provinces 840 of Zamora to Badajoz on the Spanish one, and finally the Southern coastal zone of Algarve and Huelva.

840


On the other hand, we see that whatever the statistical measure considered, the density pattern and trend on both is similar (Figures 7,8 , and values in the three years selected, we observe a significant strengthening in population relocation on the Northern and Southern coasts, as well as a dual trend in the central interior region with a rise in density up until the middle of the twentieth century and a subsequent decline accompanied by a concentration phenomenon in medium-sized cities, as is the case of Bragança and Zamora, Guarda and Salamanca, Castelo Branco and Plasencia, Evora and Badajoz.

855 Finally, spatial distribution of the three measures (density, spatial correlation, and trend) in the three suggested subregions is no more than the continuation of a spatial pattern that is visible in the wider areas on either side of the border, which the frontier does not break (Figures 7, 8, and 9,

860 compare respectively to Figures 2,3 , and 4). The population movement toward the coast referred to on both sides of the border is much a part of an extensive phenomenon that can be seen on the Atlantic Coast, for example, from Corunna to Setubal. In the inland, the growth and subsequent decline

865 that occurs, for example, in the border region between Extremadura and Alentejo, begins in Castilla-La Mancha and extends itself to the Alentejo coast.

\section{Conclusion}

In Portugal and Spain, the modernization process began with the liberal revolutions of the 1830s. In fact, these revolutions implied a profound institutional change that created the conditions for the development of a capitalist economy. Gradually, the two countries then watched the transformation of their economies, driven by the spread of railways and of industry, a process that was accompanied by urban growth. However, until the first half of the twentieth century these developments were relatively moderate, especially compared to what occurred after the Second World War, a time of significant economic growth and structural transformation, which

880 included a vigorous urban development and major movements of rural-urban migration.

This work confirmed the existence of a pattern of population distribution common to the whole Iberian Peninsula. In fact, Local Moran indicator maps identified a persistent large zone of low population density clusters, extending from the Pyrenees to the South of Portugal. With the exception of some areas, where it stretches to the sea, this low population density zone corresponds to the inland of the Peninsula. Its densities contrast with coastal ones, where urban life has

890 strongly developed. We also found that this pattern of distribution evolved similarly in the peninsular territory. We have also seen that this development did not substantially alter the relative positions of the parishes and municipalities regarding values of population density between the beginning and end of the study period, a fact which had been registered for 895 Spain as stated in the introduction.

The pattern of population distribution is clearly associated with geographical factors, in particular, altitude, distance from shore, distance to main rivers, temperature, and precipitation. These factors seem to have more weight in 900 explaining changes between $1877 / 78$ and 1940 than in the following period. The explanation suggested by Ayuda et al. (2010b) for a similar observation in relation to Spain may be valid regarding the Iberian Peninsula as a whole. In fact, geography would have strongly conditioned population lo- 905 cation in the period prior to modern economic growth. When this began, economic activity tended to concentrate in the more populated areas. The latter will benefit from migratory movements, economies of scale, and lowering transport costs and thus will grow faster than others. In this context, as time 910 goes on geographical factors continue to be of importance but decrease their explanatory weight.

Lastly, the observation of the cross-border region has shown that proximity to the frontier has not generated, either in the spatial distribution of population density or in 915 the temporal evolution, any distinct pattern on either side of the boundary line. This is consistent with what Maria Moreira (2001) said on the demographic behavior of these areas throughout the twentieth century. In reality, the density in border areas seems to be influenced by geographical fac- 920 tors and economic forces that are felt in the wider regions where those areas are integrated, which act similarly on both sides of that political divide.

The spatial coherence of the observed phenomena throughout the Peninsula and of its evolution, independent of the bor- 925 der between states, reinforces the importance of geographic factors in their explanation. At the same time, this verification opens up new issues related to the effect of economic policies, particularly in two areas related to the morphology of the territory and resources (i.e., transport and agriculture): 930 Were they very different, yet without contravening the natural constraints? Or, as it seems to have been the case, were they identical and parallel in time? If so, what is the explanation for their similarity and simultaneity? The answer to this last question should probably be sought in the insertion of two 935 states in the international political and economic context.

\section{NOTES}

1. Information available at http://www.igeo.pt/produtos/cadastro/caop/ caop_vigor.htm and http://centrodedescargas.cnig.es/CentroDescargas/equ ipamiento.do?method $=$ mostrarEquipamiento.

2. http://www.opengis.uab.es/wms/iberia/en_index.htm.

3. Population of a parish in the initial year was allocated to the corresponding parishes of the target year, according to the weight of each of the latter in the total population of this set of units in 2001.

\section{REFERENCES}

Anselin, L. 1995. Local Indicators of Spatial Association-LISA. Geographical Analysis 27:93-115. 
Ayuda, M. I., F. Collantes, and V. Pinilla. 2010a. Long-Run regional population disparities in Europe during modern economic growth: A case study of Spain. The Annals of Regional Science 44(2):273-95.

2010b. From locational fundamentals to increasing returns: The spatial concentration of population in Spain, 1787-2000. Journal of Geographical Systems 12(1):25-50.

Bairoch, P. 1971. Le tiers-monde dans l'impasse. Paris: Gallimard.

955 Carreras, A., and X. Tafunell. 2010. Historia económica de la España Contemporánea (1789-2009). Barcelona: Crítica.

Cavaco, C. 1973. A região da fronteira do Rio Minho. Lisboa: Centro de Estudos Geograficos.

- 1995. As regiões de fronteira: Inovação e desenvolvimento na perspectiva do mercado único europeu. Lisboa: Universidade de Lisboa.

Collantes, F., and V. Pinilla. 2011. Peaceful surrender: The depopulation of rural Spain in the twentieth century. Tyne: Cambridge Scholars Publishing.

Combes, P.-P., T. Mayer, and J.-F. Thisse. 2006. Économie géographique. L'Intégration des régions et des nations. Paris: Economica.

Cos Guerra, O., and P. Reques Velasco. 2005. Los cambios en los patrones territoriales de la población española (1900-2001). Papeles de Economía Española 104:167-92.

Costa, L. F., P. Lains, and S. Munch Miranda. 2012. História económica de Portugal, 1143-2010. Lisboa: Esfera dos Livros.

Dobado González, R. 2006. Geografía y desigualdad económica y demográfica de las provincias españolas (siglos XIX y XX). Investigaciones de Historia Económica 5:133-70.

Ferrão, J., I. Margarida André, J. Macaísta Malheiros, T. Sá Marques, and

975 T. Pinto-Correia. 2005. População e Território. In Geografia de Portugal, edited by Carlos Alberto Medeiros, 50-173. Lisboa: Círculo de Leitores.

Goerlich Gisbert, F. J., and M. Mas Ivars, ed. 2006. La localizacio'n de la poblacio'n espan $\sim$ ola sobre el territorio: Un siglo de cambios. Un estudio basado en series homoge' neas (1900-2001). Bilbao: Fundacio'n BBVA.

980 . 2008. Los motores de la aglomeración en España. Geografía versus Historia. Documentos de Trabajo (Fundación BBVA) 5:5-46.

Gregory, I. N., and P. Ell. 2007. Historical GIS: Technologies, methodologies, and scholarship. Cambridge: Cambridge University Press.

Kendall, M. G. 1975. Rank correlation methods. London: Charles Griffin.

985 Krugman, P. 1993. First nature, second nature, and metropolitan location. Journal of Regional Science 33(2):129-44.

. 1998. What's new about the new economic geography? Oxford Review of Economic Policy 14(2):7-17.

Lois-González, R. C. 2004. A model of Spanish-Portuguese urban growth: The Atlantic axis. Dela 21:281-94.

López Trigal, L., and F. Guichard. 2000. La frontera hispano-portuguesa: Nuevo espacio de atracción y cooperación. Zamora: Fundación Rei Afonso Henriques.

Mann, H. B. 1945. Nonparametric tests against trend. Econometrica 13(3):245-59.

Marques, A. H. de Oliveira. 1987. Portugal na crise dos séculos XIV e XV. Lisboa: Presença.

Marques, A. H. de Oliveira, and J. José Alves Dias. 2003. Atlas Histórico de Portugal e do Ultramar Português. Lisboa: Centro de Estudos Históricos.

Martí-Henneberg, J. 2005. Empirical evidence of regional population concentration in Europe, 1870-2000. Population, Space and Place 11(4):269-81.

Mellinger, A. D., J. D. Sachs, and J. L. Gallup. 2000. Climate, coastal proximity, and development. In The Oxford Handbook of Economic Ge ography, edited by G. L. Clark, M. P. Feldman, and M. S. Gertler, 170-94. 1005 Oxford: Oxford University Press.

Moreira, M. João Guardado. 2001. A dinâmica demográfica na região do Interreg Ibérico no final do século XX. Lisboa: Universidade Nova de Lisboa.

Ninyerola i Casals, M., X. Pons, and J. M. Roure i Nolla. 2005. Atlas 1010 climático digital de la Península Ibérica: Metodología y aplicaciones en bioclimatología y geobotánica. Barcelona: Universitat Autònoma de Barcelona.

. 2007a. Monthly precipitation mapping of the Iberian Peninsula using spatial interpolation tools implemented in a geographic information 1015 system. Theoretical and Applied Climatology 89:195-209.

. 2007b. Objective air temperature mapping for the Iberian Peninsula using spatial interpolation and GIS. International Journal of Climatology 27:1231-42.

Paluzie, E., J. Pons Novell, J. Silvestre, and D. A. Tirado Fabregat. 2009. 1020 Migrants and market potential in Spain over the twentieth century: A test of the new economic geography. Spanish Economic Review 11(4):243-65.

Pérez Moreda, V. 2004. El legado demográfico del Antiguo Régimen. In El legado económico del antiguo régimen en España, 121-46. Barcelona: Crítica.

\section{0}

Pires, I. M., and D. Pimentel. 2004. Revisitando a região transfronteiriça ibérica: Potencialidades e estrangulamentos nos novos contextos de integração ibérica. In $V$ Congresso da Geografia Portuguesa. Portugal: Territórios e protagonistas. Lisboa: Associação Portuguesa de Geógrafos. http://www.apgeo.pt/files/docs/CD_V_Congresso_APG/web/_pdf/xD78_14Out_Iva\%20Pires-Dulce\%20Pimentel.pdf.

Reher, D. S. 1994. Ciudades, Procesos De Urbanización y Sistemas Urbanos En La Península Ibérica, 1550-1991. In Atlas Histórico De Ciudades Europeas: Península Ibérica, edited by M. Guàrdia i Bassols, F. Xavier Monclús, and J. Luis Oyón, 1-30. Barcelona: Salvat.

Ribeiro, O. 1945. Portugal o Mediterrâneo e o Atlântico: Estudo geográfico. Coimbra: Coimbra Editora.

Rodrigues, T., ed. 2008. História da população portuguesa: Das longas permanências à conquista da modernidade. Porto: CEPESE (Centro de Estudos da População, Economia e Sociedade).

Sen, P. K. 1968. Estimates of the regression coefficient based on Kendall's Tau. Journal of the American Statistical Association 63(324):1379-89.

Silveira, L. Espinha da, D. Alves, N. Miguel Lima, A. Alcântara, and J. Puig. 2011. Population and railways in Portugal, 1801-1930. Journal of Interdisciplinary History 42(1):29-52.

Tirado Fabregat, D. A., and M. Badia-Miró. 2012. Economic integration and regional inequality in Iberia (1900-2000): A geographical approach. Working Papers in Economic History (12-03). http://orff.uc3m.es/handle/10016/13688.

Tortella, G. 1994. El desarrollo de la España Contemporánea. Historia 1050 Económica de los Siglos XIX y XX. Madrid: Alianza Universidad.

Wood, A., and S. Roberts. 2011. Economic geography: Places, networks and flows. Abingdon: Routledge. 